Article

\title{
Nutrient enrichment and its effect on the phytoplankton community of Hrazdan River in the Yerevan District, Republic of Armenia
}

\author{
Lilit G. Stepanyan`®, Evelina Kh. Ghukasyan $\odot$
}

Institute of Hydroecology and Ichthyology of the Scientific Center of Zoology and Hydroecology, National Academy of Sciences of the Republic of Armenia, P. Sevak str. 7, 0014, Yerevan, Armenia

*listeus@mail.ru

Received: 29.03 .2021

Revised: 17.05.2021

Accepted: 27.05.2021

Published online: 17.08 .2021

DOI: $10.23859 /$ estr-210329

UDC 574.52

\begin{abstract}
The phytoplankton community and nutrient enrichment of Hrazdan River have been studied in the Yerevan District, Republic of Armenia. Water was sampled in spring and summer of 2019. The content of phosphate, ammonium, and nitrite ions were significantly higher downstream of the Yerevan District compared to the stations located upstream. The latter were characterized by higher abundance of diatoms (Melosira varians and Rhoicosphenia curvata), while Oscillatoria limnetica, O. chlorina, and Anabaena sphaerica dominated downstream, reflecting different eutrophic state of the river parts.
\end{abstract}

Key words: Hrazdan River, phytoplankton community, nutrient enrichment.

To cite this article. Stepanyan, L.G., Ghukasyan, E.Kh., 2021. Nutrient enrichment and its effect on the phytoplankton community of Hrazdan River in the Yerevan District, Republic of Armenia. Ecosystem Transformation 4 (3), 3-12. https://doi.org/10.23859/estr-210329

\section{Introduction}

Rivers passing through megacities are exposed to high threat by various anthropogenic activities. Particularly, industrial and household wastewater discharge is the common source for organic load into the aquatic ecosystems (Adeyemo et al., 2008). Such a load poses huge risks for all aquatic organisms and, in particular, for phytoplankton communities. The distribution of different algae species depends on interactions between environmental abiotic and biotic factors. Deterioration of environmental conditions due to increased organic matter income leads to obvious changes in phytoplankton community, promoting succession from diatoms to Cyanophyta. Therefore, the use of phytoplankton as an indicator for ecological status of surface water bodies is widely accepted (Reynolds et al., 2002; Swaminathan, 2003).

Hrazdan River is one of the major tributaries of Araks River on the territory of the Republic of Armenia. It flows from Lake Sevan through the Sevan, Hrazdan, Charentsavan, Abovyan, and Yerevan cities; its length is $141 \mathrm{~km}$. However, negative effect of Yerevan city on ecological status of the river exceeds the cumulative negative effect of all the settlements upstream. The water of Hrazdan River is used for irrigation, energetic, industrial, and other purposes (Chilingaryan et al., 2002, Stepanyan, 2009).

The study aims to assess the nutrient enrichment and corresponding changes in phytoplankton community of Hrazdan River on the territory of Yerevan District. 
Table 1. Brief characteristics of sampling sites.

\begin{tabular}{|c|c|c|c|}
\hline Station no. & Latitude & Longitude & Description of sampling site \\
\hline 1 & $\mathrm{~N} 40.280873^{\circ}$ & E $44.589203^{\circ}$ & Getamej village, upstream Yerevan City \\
\hline 2 & $\mathrm{~N} 40.171^{\circ}$ & E $44.499669^{\circ}$ & City center of Yerevan \\
\hline 3 & N 40.159089 & E $44.1389^{\circ}$ & $\begin{array}{l}\text { Upstream Yerevanyan Lich Reservoir, } \\
\text { downstream the confluence site of Djhrvejh } \\
\text { and Getar tributaries }\end{array}$ \\
\hline 4 & $\mathrm{~N} 40.148791^{\circ}$ & E $44.589203^{\circ}$ & $\begin{array}{c}\text { Verin Charbakh district, downstream of } \\
\text { Yerevanyan Lich Reservoir }\end{array}$ \\
\hline
\end{tabular}

Table 2. The hydrophysical parameters and water $\mathrm{pH}$ in Hrazdan River at the territory of Yerevan District. $\mathrm{T}$ - water temperature, $\mathrm{V}-$ flow velocity.

\begin{tabular}{ccccccccc}
\hline \multirow{2}{*}{ Parameters } & \multicolumn{2}{c}{1} & \multicolumn{2}{c}{ Station } & \multicolumn{2}{c}{ 3 } & \multicolumn{2}{c}{4} \\
& Spring & Summer & Spring & Summer & Spring & Summer & Spring & Summer \\
\hline $\mathrm{T},{ }^{\circ} \mathrm{C}$ & 13 & 16 & 14 & 21 & 15 & 20 & 15 & 25 \\
$\mathrm{~V}, \mathrm{M} / \mathrm{C}$ & 0.3 & 0.6 & 0.7 & 0.5 & 0.2 & 0.4 & 1 & 0.6 \\
$\mathrm{pH}$ & 7.5 & 7.2 & 8.2 & 8.5 & 8.1 & 7.9 & 8.0 & 8.2 \\
\hline
\end{tabular}

\section{Material and methods}

Study was carried out during spring (May) and summer (July) seasons of 2019. Water was sampled at four stations for hydrochemical and hydrobiologic analyses (Table 1).

The phytoplankton community was analyzed by the standard methods (Abakumov, 1983). A 1-L water sample was taken from each site and immediately fixed with $40 \%$ formaldehyde solution $(0.4 \%$ final concentration) and stored in a dark place until the total sedimentation of seston. The laboratory analyses were performed according to V.A. Abakumov (1983).

Quantitative and qualitative analyses of phytoplankton were performed under a microscope in the 0.01-mL Nageotte chamber. Phytoplankton biomass was calculated by the stereometric (cell volume) method.

The species of planktonic algae were identified by the taxonomic keys and the manuals for freshwater ecosystems (Hambaryan and Shahazizyan, 2014; Proshkina-Lavrenko and Makarova, 1968; Streble and Krauter, 2001; Tsarenko, 1990).

Water temperature and velocity were measured at the sampling site. Hydrochemical parameters such as DO (dissolved oxygen) and $\mathrm{pH}$ were measured in parallel with the hydrophysical parameters by Milwaukee (PH 56 PRO) Waterproof pH meter and Milwaukee (MW 600) Dissolved Oxygen meter. The nutrients' concentrations were measured in the laboratory according to the ISO methods by spectrophotometer. Ammonium nitrogen concentration was determined according to the ISO 5664:2006, nitrite nitrogen, ISO 6777:1984, nitrate nitrogen, ISO 6777:1984, and phosphate phosphorus, ISO 6878.

\section{Results and discussion}

\section{Abiotic parameters}

The hydrophysical parameters are presented in Table 2. Water temperature ranged from 13 to $25^{\circ} \mathrm{C}$, flow velocity, from 0.2 to $1.0 \mathrm{~m} / \mathrm{s}$.

According to A.M. Nikanorov (2001), the optimal $\mathrm{pH}$ range for sustainable aquatic life varies from 6.5 to 8.5. Thus, optimal $\mathrm{pH}$ conditions have been registered at all stations of the studied part of Hrazdan River (Table 2).

Generally, the dissolved oxygen concentration (DO) was lower in summer than in spring. Moreover, DO was significantly higher upstream Yerevan city than at the other stations. The lowest DO concentration $\left(2.9 \mathrm{mgO}_{2} / \mathrm{L}\right)$ was registered at the station no. 3 in summer, partly due to the urban sewage discharge brought to this site by the Getar River, a tributary of the Hrazdan River (Fig. 1).

Similarly to 2003-2006 (Stepanyan, 2009), significant nutrient enrichment has recorded in the Hrazdan River in 2019. Nitrate content was high at the stations nos. 1 and 3 , which was still within the 


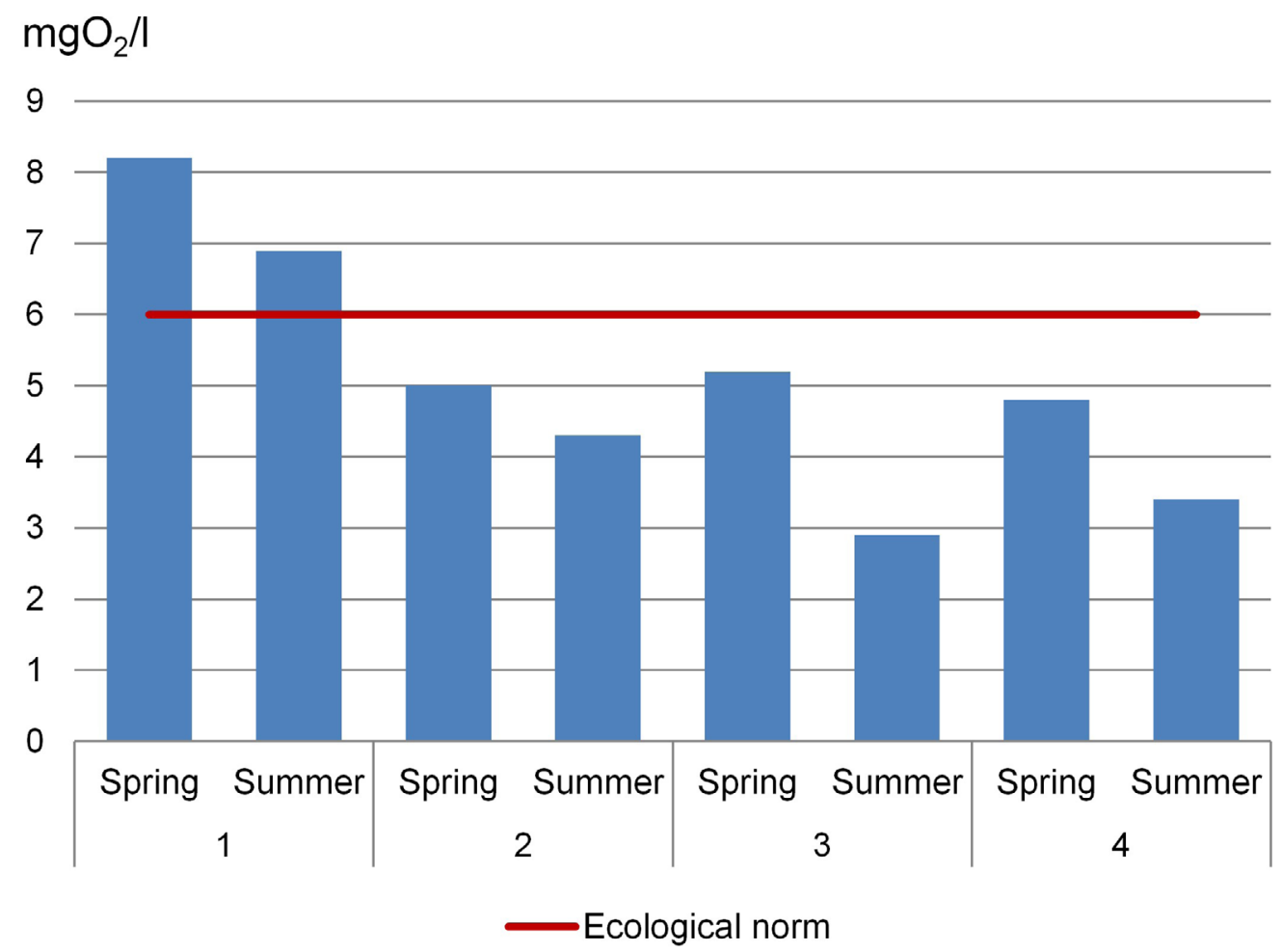

Fig. 1. Dissolved oxygen concentration at the sampling sites. Hereinafter, the background environmental values are indicated according to State Standards of Republic of Armenia.

\section{$\mathrm{mgN} / \mathrm{l}$}

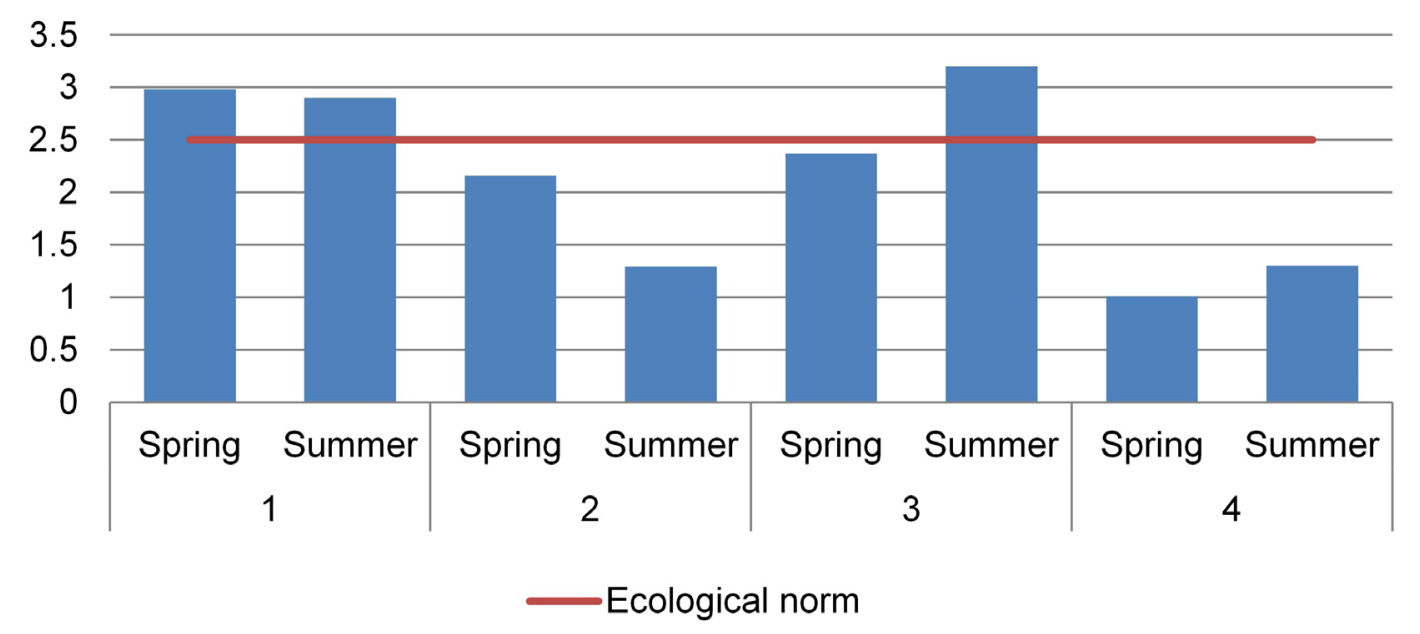

Fig. 2. Nitrate concentrations at the sampling sites.

ecological norm standards for the river ecosystem health and biodiversity conservation ${ }^{1}$ (Fig. 2).

The concentrations of nitrite and ammonium ions in the riverine waters usually varied from hundredths to tenths of a milligram per liter (Figs. 3, 4). Within our

\footnotetext{
${ }^{1}$ Government Decision No. 75-N "On defining the standards for water quality of each water basin management area depending on local characteristics". Web page. URL: https://www.e-gov.am/u files/file/decrees/kar/2011/02/11_0075.pdf (accessed: 27.01.2021)
}

study, nitrite content varied from 0.01 to $0.32 \mathrm{mgN} / \mathrm{L}$. In summer, nitrite content significantly increased at the stations located within the Yerevan city (stations nos. 2, 3, and 4).

Ammonium concentration also exceeded ecological norm at the stations nos. 3 and 4 at both seasons (Fig. 4). High nitrite and ammonium content corresponds to the eutrophic status of the waters (Nikanorov, 2001).

Phosphate concentrations were exceptionally high in summer almost at all sampling sites except 


\section{$\mathrm{mgN} / \mathrm{l}$}

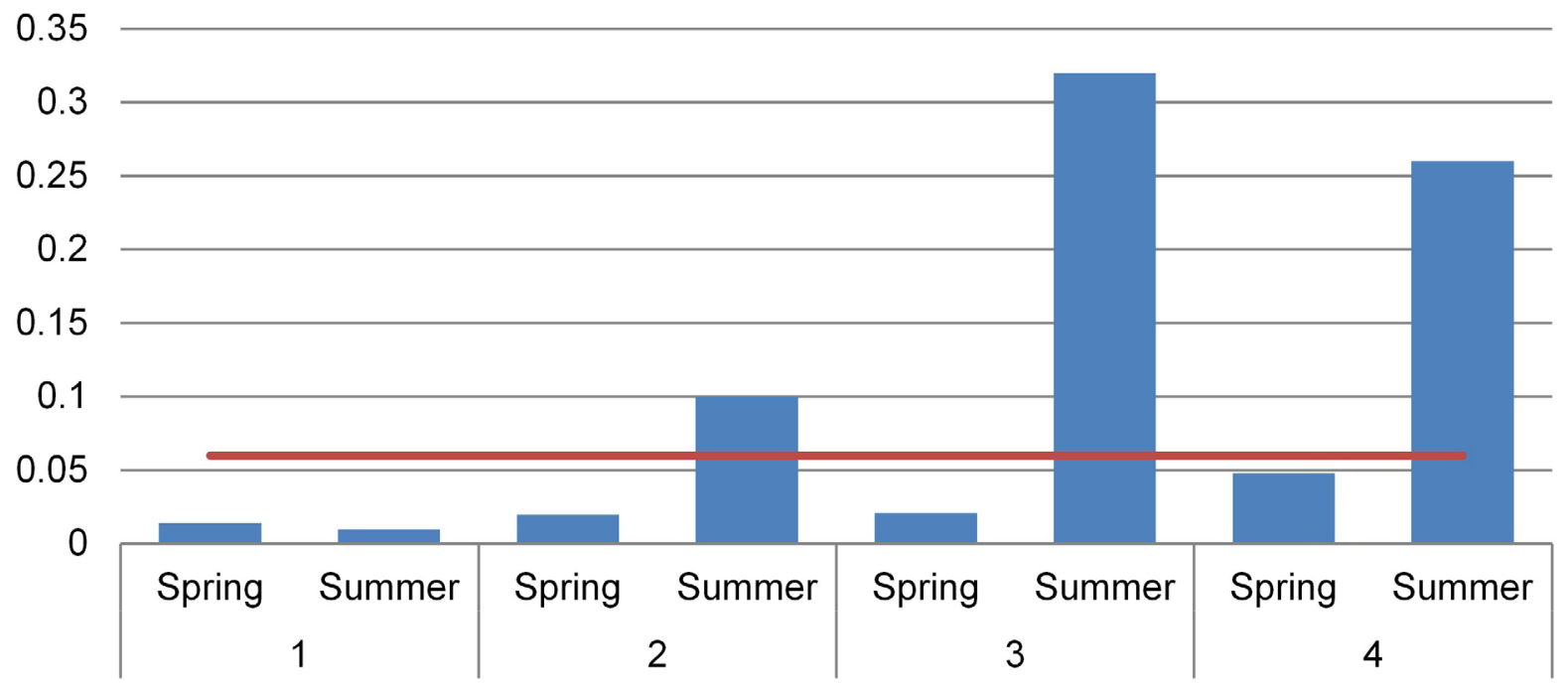

Fig. 3. Nitrite concentrations at the sampling sites.

Ecological norm

\section{$\mathrm{mgN} / \mathrm{l}$}

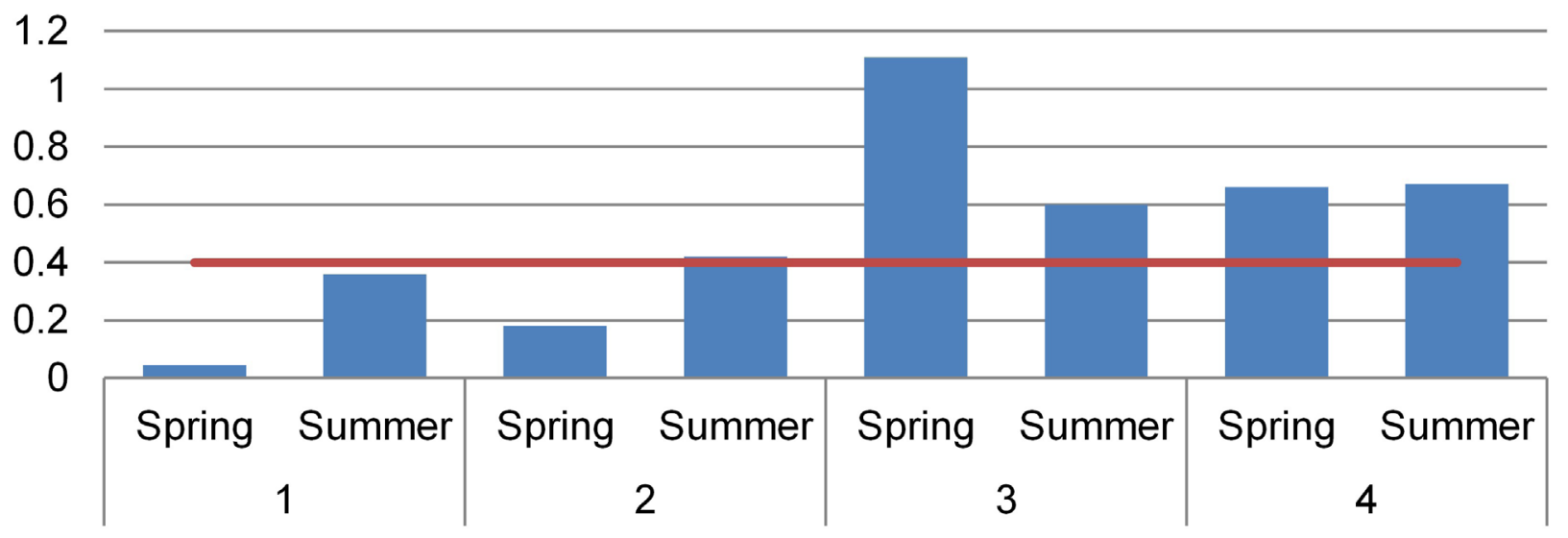

Fig. 4. Ammonium concentrations at the sampling sites.

station no. 4 (Fig. 5). Such pattern observed downstream Yerevanyan Lich Reservoir could be explained by the algal bloom in the reservoir itself. As the algae consume phosphates, a bloom may minimize the phosphate content in the outflowing water.

\section{Phytoplankton community}

Earlier studies of phytoplankton carried out in 2004-2006 in Hrazdan River at the territory of Yerevan District revealed 108 species belonging to six phytoplankton groups (Stepanyan, 2009).
During present study of phytoplankton community, 55 species belonging to six phytoplankton groups have been registered (Table 3 ). As found generally, diatoms dominated, but Cyanophyta were characterized by higher abundance than usually observed. Although some species of Dinophyta and Euglenophyta, new groups of algae for Hrazdan River, were recorded in 2019, total species diversity of phytoplankton decreased comparing to previous studies (Badalyan et al., 2005; Stepanyan et al., 2005; Stepanyan, 2009). 
Table 3. List of phytoplankton species at the sampling sites. "+" - species is present; "-" - species is absent. Chorological types (Geo): c-cosmopolite; b - boreal, a-a - Arctic-Alpine. Halobity (Hal): mh - mesohalobe; i - oligohalobe-indifferent; hl - oligohalobe-halophilous; $\mathrm{hb}$ - oligohalobe-halophobous. Habitat types (Hab): B - benthic; P - planktonic; P-B - planktonic-benthic. Saprobity (S): o - oligosaprobic; o- $\beta$ - oligo-beta-mesosaprobic; $\beta$ - beta-mesosaprobic; $\beta$-o - beta-oligomesosaprobic; $\beta$ - $\alpha$ - beta-alfa-mesosaprobic; $\alpha-\beta$ - alfa-betamesosaprobic; $x$ - xenosaprobic; $x-0$ - xeno-oligosaprobic; $x-\beta$ - xeno-beta-mesosaprobic; o- $x$ - oligo-xenosaprobic, o- $\alpha$ - oligo-alfamesosaprobic; $p$ - polysaprobic; "-" - no data (Barinova et al, 2006).

\begin{tabular}{|c|c|c|c|c|c|c|c|c|}
\hline & $\begin{array}{c}1 \\
\text { (spring/ } \\
\text { summer) }\end{array}$ & $\begin{array}{c}2 \\
\text { (spring/ } \\
\text { summer) }\end{array}$ & $\begin{array}{c}3 \\
\text { (spring/ } \\
\text { summer) }\end{array}$ & $\begin{array}{c}4 \\
\text { (spring/ } \\
\text { summer) }\end{array}$ & Geo & Hal & $\mathrm{Hab}$ & $S$ \\
\hline \multicolumn{9}{|l|}{ Cyanophyta } \\
\hline $\begin{array}{l}\text { Anabaena sphaerica } \\
\text { Bornet \& Flahault }\end{array}$ & $-1-$ & $-1-$ & $-1-$ & $-/+$ & c & $\mathrm{i}$ & $P$ & $0-\beta$ \\
\hline $\begin{array}{l}\text { Aphanothece clathrata } \\
\text { West \& G.S. West }\end{array}$ & $+/+$ & $+/-$ & $+/+$ & $+/+$ & c & $\mathrm{i}$ & $P$ & $\beta$ \\
\hline Microcystis aeruginosa Kutzing & $+/+$ & $-/+$ & $+/+$ & $+/+$ & c & $\mathrm{hl}$ & $P$ & $0-\alpha$ \\
\hline $\begin{array}{l}\text { M. wessenbergii } \\
\text { Komárek in Joosen }\end{array}$ & $+/+$ & $+/+$ & $+/+$ & $+/+$ & c & - & $P$ & $0-\alpha$ \\
\hline $\begin{array}{l}\text { Oscillatoria chlorina } \\
\text { Kützing ex Gomont }\end{array}$ & $-1-$ & $-1-$ & $-/+$ & $+/+$ & c & - & P-B & $\mathrm{p}$ \\
\hline $\begin{array}{l}\text { Oscillatoria limnetica } \\
\text { Lemmermann }\end{array}$ & $-1-$ & $-1-$ & $-/+$ & $-1+$ & c & - & P-B & $0-\beta$ \\
\hline \multicolumn{9}{|l|}{ Bacillariophyta } \\
\hline Achnanthes taeniata Grunow & $-1+$ & $-1-$ & $+/+$ & $+/-$ & - & $\mathrm{hl}$ & B & - \\
\hline $\begin{array}{l}\text { Amphora ovalis } \\
\text { (Kützing) Kützing }\end{array}$ & $-/+$ & $-1-$ & $+/-$ & $-1+$ & c & i & $B$ & $\alpha-\beta$ \\
\hline $\begin{array}{l}\text { Ceratoneis arcus } \\
\text { (Ehrenberg) Kützing }\end{array}$ & $-1-$ & $-1-$ & $+/-$ & $-1-$ & $a-a$ & $\mathrm{i}$ & B & $0-x$ \\
\hline $\begin{array}{c}\text { Cocconeis placentula } \\
\text { Ehrenberg }\end{array}$ & $+/+$ & $-/+$ & $-/+$ & $+/+$ & c & $\mathrm{i}$ & P-B & $0-\beta$ \\
\hline C. pediculus Ehrenberg & $-/+$ & $-1-$ & $-1-$ & $-/+$ & c & i & $B$ & $0-\alpha$ \\
\hline Cyclotella comta Kützing & $+/-$ & $-1-$ & $-1-$ & $-1-$ & c & i & $P$ & $\beta-0$ \\
\hline $\begin{array}{c}\text { C. stelligera } \\
\text { (Cleve \& Grunow) Van Heurck }\end{array}$ & $+/-$ & $-1-$ & $-1-$ & $-1-$ & c & $\mathrm{i}$ & P-B & $x$ \\
\hline $\begin{array}{l}\text { Cymatopleura solea } \\
\text { (Brébisson) W. Smith }\end{array}$ & $-1-$ & $-1-$ & $-/+$ & $-1-$ & c & i & P-B & 0 \\
\hline $\begin{array}{l}\text { Cymbella prostrata } \\
\text { (Berkeley) Cleve }\end{array}$ & $-1-$ & $-1-$ & $-1-$ & $-/+$ & c & i & B & $0-\beta$ \\
\hline C. ventricosa C. Agardh & $+/+$ & $-1-$ & $-1-$ & $-/+$ & c & $\mathrm{i}$ & B & $0-\alpha$ \\
\hline $\begin{array}{l}\text { Diatoma hiemale var. hiemale } \\
\text { (Roth) Heib }\end{array}$ & $+/+$ & $+1-$ & $+/+$ & $+/+$ & c & hb & P-B & $\beta-0$ \\
\hline D. vulgaris Bory & $+/-$ & $-1-$ & $-1-$ & $-1-$ & c & $\mathrm{i}$ & P-B & $\beta$ \\
\hline $\begin{array}{l}\text { Fragilaria capucina } \\
\text { Desmazières }\end{array}$ & $+/+$ & $-1+$ & $+/+$ & $+/+$ & c & $\mathrm{i}$ & B & 0 \\
\hline $\begin{array}{l}\text { F. construens } \\
\text { (Ehrenberg) Grunow }\end{array}$ & $+/+$ & $-1-$ & $-1-$ & $-/+$ & c & $\mathrm{i}$ & P-B & 0 \\
\hline F. crotonensis Kitton & $+/-$ & $+/-$ & $+/+$ & $+/+$ & c & $\mathrm{hl}$ & $P$ & $\alpha-\beta$ \\
\hline
\end{tabular}




\begin{tabular}{|c|c|c|c|c|c|c|c|c|}
\hline & $\begin{array}{c}1 \\
\text { (spring/ } \\
\text { summer) }\end{array}$ & $\begin{array}{c}2 \\
\text { (spring/ } \\
\text { summer) }\end{array}$ & $\begin{array}{c}3 \\
\text { (spring/ } \\
\text { summer) }\end{array}$ & $\begin{array}{c}4 \\
\text { (spring/ } \\
\text { summer) }\end{array}$ & Geo & $\mathrm{Hal}$ & $\mathrm{Hab}$ & $S$ \\
\hline $\begin{array}{l}\text { Gomphonema constrictum } \\
\text { Ehrenberg in Kützing }\end{array}$ & $-/+$ & $-1-$ & $-1+$ & $-1-$ & c & $\mathrm{i}$ & B & 0 \\
\hline $\begin{array}{l}\text { Gomphonema olivaceum } \\
\text { (Hornemann) Brébisson }\end{array}$ & $+/-$ & $-1-$ & $+/-$ & $-1-$ & c & $\mathrm{i}$ & B & $\beta-\alpha$ \\
\hline Melosira varians C. Agardh & $+/+$ & $+/+$ & $+/-$ & $+/+$ & c & $\mathrm{hl}$ & P-B & $\alpha-\beta$ \\
\hline Navicula cryptocephala Kutz. & $+/-$ & $-1-$ & $+/+$ & $+/+$ & c & $\mathrm{i}$ & B & $x-0$ \\
\hline N. menisculus Schumann & $-1-$ & $+/-$ & $-1-$ & $-1-$ & c & $\mathrm{i}$ & $B$ & $x-\beta$ \\
\hline N. pupula Kützing & $+/-$ & $-1-$ & $-1-$ & $-1-$ & c & $\mathrm{hl}$ & $B$ & $x-0$ \\
\hline N. pygmaea Kützing & $-1-$ & $-1-$ & $-1+$ & $-1-$ & c & $\mathrm{mh}$ & - & $\beta-0$ \\
\hline N. radiosa Kutzing & $-1-$ & $-1-$ & $+/-$ & $-1-$ & c & $\mathrm{i}$ & B & 0 \\
\hline N. rhyncocephala Kutz & $-1-$ & $-1-$ & $+/-$ & $-1-$ & c & $\mathrm{hl}$ & B & $\beta$ \\
\hline Nitszchia amphibia Grunow & $-1-$ & $-1+$ & $-1-$ & $-1-$ & c & $\mathrm{i}$ & P-B & o \\
\hline $\begin{array}{l}\text { N. dissipata } \\
\text { (Kützing) Rabenhorst }\end{array}$ & $-1-$ & $-1-$ & $+/-$ & $-1-$ & c & $\mathrm{i}$ & B & $x$ \\
\hline N. linearis W. Smith & $-1-$ & $-1-$ & $-1-$ & $+/-$ & c & $\mathrm{i}$ & B & $x$ \\
\hline Pinnularia virdis Ehrb. & $+/+$ & $+/+$ & $+/+$ & $-/+$ & c & $\mathrm{i}$ & P-B & $0-x$ \\
\hline P. leptosoma (Grunow) Cleve & $+/+$ & $-1-$ & $+/-$ & $-1-$ & $b$ & $\mathrm{i}$ & B & 0 \\
\hline $\begin{array}{l}\text { Rhoicophenia curvata } \\
\text { (Kutzing) Grunow }\end{array}$ & $+/-$ & $+/+$ & $-1+$ & $-1+$ & c & $\mathrm{i}$ & P-B & $x-0$ \\
\hline $\begin{array}{l}\text { Stephanodiscus astraea } \\
\text { (Kützing) Grunow }\end{array}$ & $+/-$ & $+/+$ & $-1+$ & $+/+$ & c & $\mathrm{i}$ & $P$ & $\beta$ \\
\hline $\begin{array}{c}\text { S. hantzschii } \\
\text { Grunow in Cleve \& Grunow }\end{array}$ & $-1-$ & $-1-$ & $+/-$ & $-1-$ & c & $\mathrm{i}$ & $P$ & $\alpha-\beta$ \\
\hline $\begin{array}{l}\text { Surirella biseriataBrébisson } \\
\text { in Brébisson \& Godey }\end{array}$ & $+/-$ & $-1-$ & $-1-$ & $-1-$ & c & $\mathrm{i}$ & - & $0-\beta$ \\
\hline S. ovata Kützing & $+/-$ & $-1-$ & $-1+$ & $-1-$ & c & $\mathrm{i}$ & B & $0-\alpha$ \\
\hline Surirella sp. & $-1-$ & $+/-$ & $-1-$ & $-1-$ & - & - & - & - \\
\hline S. tenera var. tenera Greg. & $-1-$ & $-1-$ & $-1+$ & $-1-$ & c & $\mathrm{i}$ & P-B & 0 \\
\hline \multicolumn{9}{|l|}{ Chlorophyta } \\
\hline $\begin{array}{l}\text { Ankistrodesmus falcutus } \\
\text { (Corda) Ralfs }\end{array}$ & $-1-$ & $-1-$ & $-1-$ & $+/-$ & c & $\mathrm{hb}$ & P-B & $\beta$ \\
\hline $\begin{array}{c}\text { Binuclearia lauterbornii } \\
\text { (Schmidle) Proschkina- } \\
\text { Lavrenko }\end{array}$ & $-1-$ & $-1+$ & $-1-$ & $-1-$ & - & - & - & - \\
\hline $\begin{array}{l}\text { Characium nasutum } \\
\text { Rabenhorst }\end{array}$ & $+/-$ & $-1-$ & $-1-$ & $-1-$ & - & - & - & - \\
\hline Chroococcus sp. & $-1-$ & $+/-$ & $-1-$ & $-1-$ & - & - & - & - \\
\hline
\end{tabular}




\begin{tabular}{|c|c|c|c|c|c|c|c|c|}
\hline & $\begin{array}{c}1 \\
\text { (spring/ } \\
\text { summer) }\end{array}$ & $\begin{array}{c}2 \\
\text { (spring/ } \\
\text { summer) }\end{array}$ & $\begin{array}{c}3 \\
\text { (spring/ } \\
\text { summer) }\end{array}$ & $\begin{array}{c}4 \\
\text { (spring/ } \\
\text { summer) }\end{array}$ & Geo & $\mathrm{Hal}$ & $\mathrm{Hab}$ & $S$ \\
\hline $\begin{array}{c}\text { Dictyosphaerium pulchellum } \\
\text { H.C. Wood }\end{array}$ & $-1-$ & $-1-$ & $-1-$ & $-1+$ & c & $\mathrm{i}$ & $P$ & $\beta$ \\
\hline Pandorina morum (Mull) Bory & $-1-$ & $-1+$ & $-1-$ & $-1-$ & c & $\mathrm{i}$ & $P$ & $\beta$ \\
\hline $\begin{array}{l}\text { Scenedesmus armatus var. } \\
\text { armatus (Chod) G.M. Smith }\end{array}$ & $-1-$ & $-1-$ & $-1-$ & $-1+$ & c & - & P-B & $0-\alpha$ \\
\hline $\begin{array}{l}\text { Scenedesmus opolensis } \\
\text { var. opolensis P. Richt. }\end{array}$ & $-1-$ & $-1-$ & $-1-$ & $-1+$ & c & - & P-B & $\beta$ \\
\hline Selenastrum gracile Reinsch & $-1-$ & $-1+$ & $-1-$ & $-1-$ & c & - & P-B & $0-\alpha$ \\
\hline $\begin{array}{c}\text { Trebouxia humicola G.S. West } \\
\text { \& F.E. Fritsch }\end{array}$ & $-1-$ & $-1-$ & $-1-$ & $+/-$ & - & - & - & - \\
\hline \multicolumn{9}{|l|}{ Euglenophyta } \\
\hline $\begin{array}{l}\text { Trachelamonas volvocina } \\
\text { (Ehrenberg) Ehrenberg }\end{array}$ & $+/-$ & $-1-$ & $-1-$ & $+/+$ & c & $\mathrm{i}$ & B & $\beta$ \\
\hline \multicolumn{9}{|l|}{ Dinophyta } \\
\hline Peridinium willei Huitfeldt-Kaas & $-1-$ & $-1-$ & $-1-$ & $-1+$ & - & $\mathrm{hl}$ & $\mathrm{P}$ & $0-\beta$ \\
\hline \multicolumn{9}{|l|}{ Xanthophyta } \\
\hline $\begin{array}{c}\text { Tribonema monochloron } \\
\text { Pascher \& Geitler in Pascher }\end{array}$ & $-1-$ & $-1-$ & $-1-$ & $-1+$ & - & - & - & - \\
\hline
\end{tabular}

Microalgal communities of the Hrazdan River are represented by benthic, planktonic, and planktonicbenthic algae, mostly by benthic algae (Table 3 ). Fortyfive phytoplankton species are indicators of organic pollution, presented mostly by $\beta$-mesosaprobic species. Four ecological groups of salinity indicators have been identified, the representatives of oligohalobe-indifferent group predominate. Most species are eurybionts.

In spring, diatoms strongly prevailed at the station no. 1, comprising $96 \%$ of phytoplankton community. Melosira varians dominated both by abundance (45\%) and biomass (53\%).

Downstream the station no. 1, there was a decrease in the quantitative parameters of phytoplankton, the dominant groups of algae changed as well. Cyanophyta prevailed at the stations nos. 3 and 4. Correspondingly, Microcystis aeruginosa and Aphanothece clathrata were the most abundant species at these stations. Representatives of Chlorophyta and Euglenophyta were also revealed in spring at the study sites.

Compared to spring, both the quantitative and qualitative parameters of microalgae increased in summer (Figs. 6, 7). However, diatoms still dominated at the stations nos. 1 and 2 due to Melosira varians and Rhoicosphenia curvata, respectively.
Significant increase of Cyanophyta abundance was registered at the stations nos. 3 and 4 following the nutrients' dynamics. Bloom of Oscillatoria species (O. limnetica and O. chlorina) was observed; they comprised $77 \%$ of the total abundance and $59 \%$ of the total biomass at the station no. 3; $75 \%$ and $59 \%$ at the station no. 4, respectively.

Oscillatoria species reach considerable abundance in naturally eutrophic and polluted streams and lakes (Babanazarova et al., 2013; Prowse, 1969). They are generally benthic by preferable habitat, but may develop actively in plankton communities. Both registered species of this genus refer to the indicators of organic pollution (Table 2) (Barinova, 2006).

Ability of Cyanophyta to produce toxins attracts much attention, especially when these species dominate in eutrophic waters, making concern to water quality (Codd, 2000). Oscillatoria species are the most common agents of freshwater toxic blooms. They produce hepatotoxin microcystin (Chia et al, 2018). Microcystin is reported to cause death of wild animals and agricultural livestock (Carmichael, 1988), it has been as well recognized as a potential threat to the human health in the countries, where water supplies are contaminated with cyanobacteria (Banerjee, 2020; Gkelis and Zaoutsos, 2014; Yu, 1989). Therefore, the bloom of Oscillatoria species 


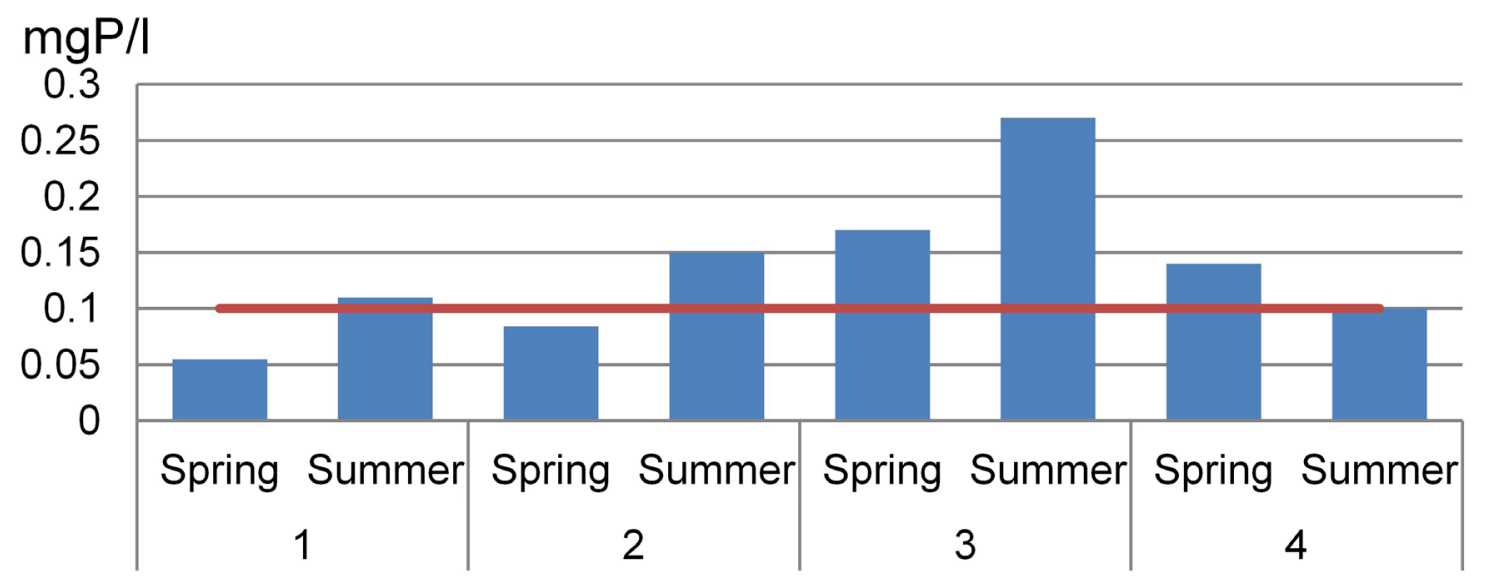

Fig. 5. Phosphate concentrations at the sampling sites.

\section{Ecological norm}

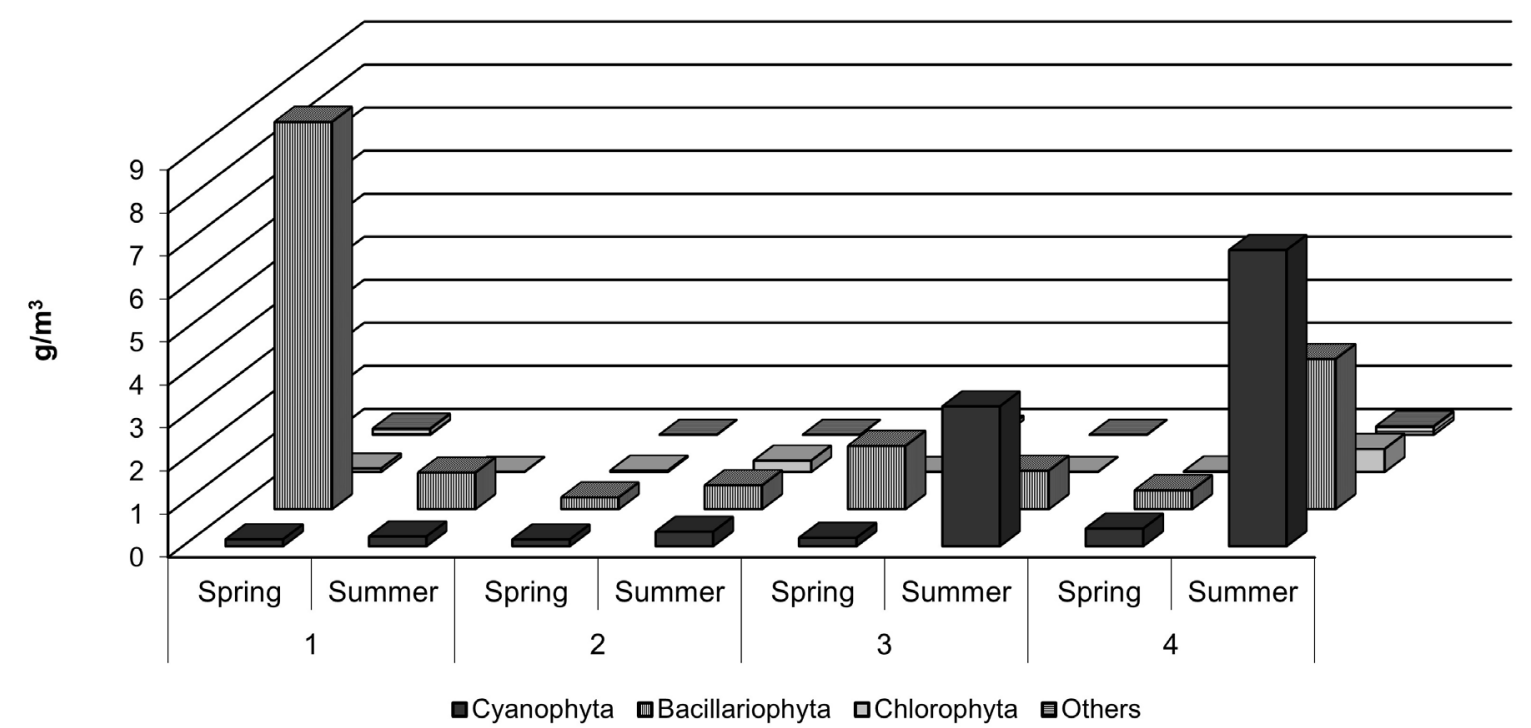

Fig. 6. Seasonal dynamics of phytoplankton abundance at the sampling sites.

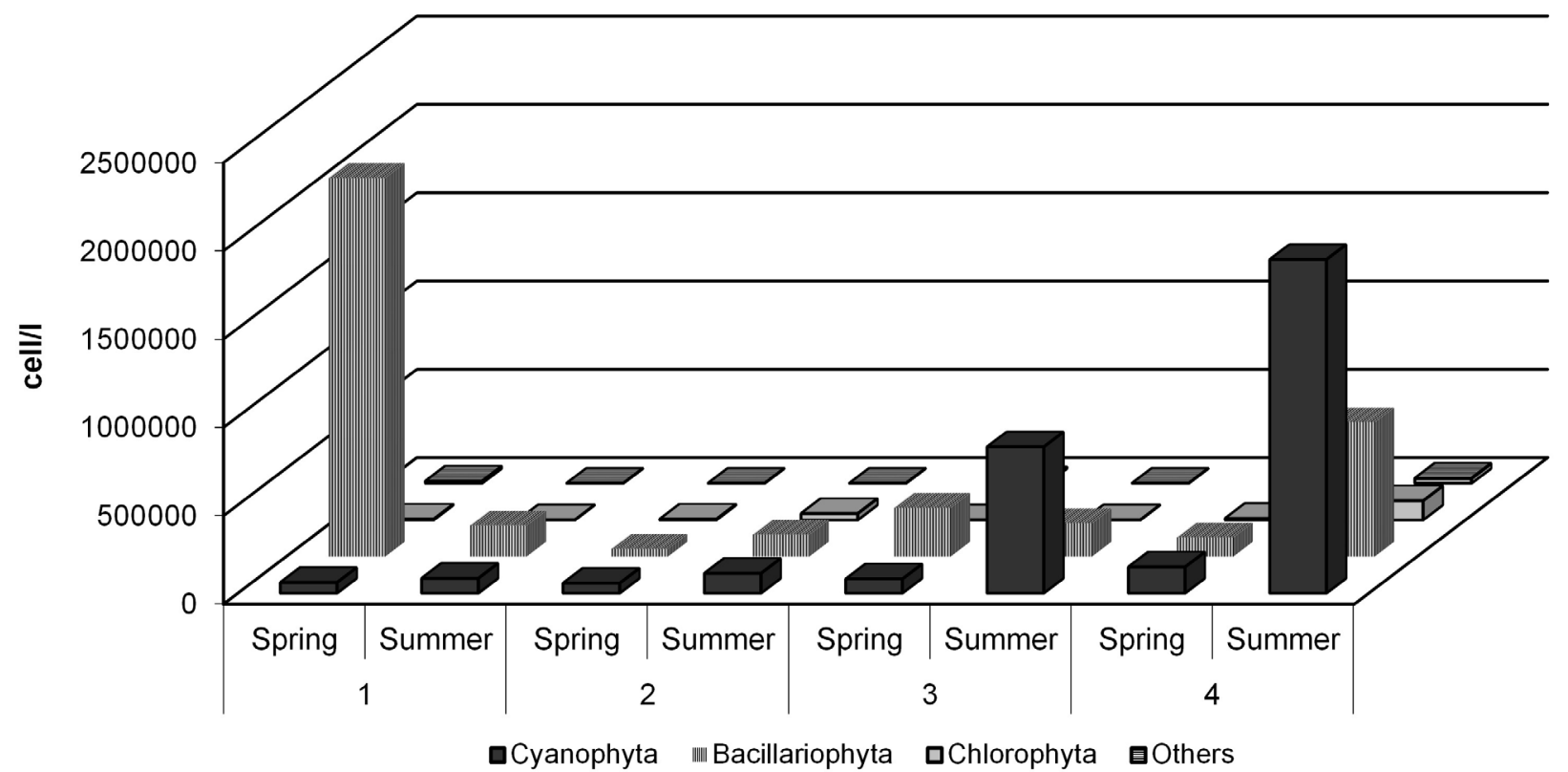

Fig. 7. Seasonal dynamics of phytoplankton biomass at the sampling sites. 
could cause a serious harm to the economy of the agriculture and recreational capacities of the area, since these sectors of economics are the main water consumers.

Abundance of nitrogen-fixing species Anabaena sphaerica $(148,000$ cell/L) were observed at the station no. 4. Our observations performed in Yerevanyan Lich reservoir during summer of 2019 evidenced on the dominance of Oscillatoria chlorina and Anabaena sphaerica, proving the impact of the reservoir on the Hrazdan River (Annual Report..., 2019).

\section{Conclusion}

As a corollary, we conclude that high content of phosphates and nitrogen lead to increase of algae growth rates and ultimately reduce dissolved oxygen concentration in water. Nutrient enrichment at the stations nos. 3 and 4 is significantly higher than at the sites located upstream. The Oscillatoria bloom has been registered in the stations nos. 3 and 4 in summer. The influence of Yerevanyan Lich reservoir on phytoplankton community of these stations is obvious. Therefore, better management and strict control of the nutrient load to Hrazdan River from Yerevan city is urgently needed.

\section{ORCID}

L.G. Stepanyan (1D) 0000-0002-0960-7234

E.Kh. Gukasyan (ID 0000-0001-8866-9785

\section{References}

Abakumov, V.A., 1983. Rukovodstvo po metodam gidrobiologicheskogo analiza poverkhnostnykh vod i donnykh otlojenij [Manual for hydrobiological analysis of surface water and sediments]. Gidrometeoizdat, Leningrad, USSR, 240 p. (In Russian).

Adeyemo, O.K., Adedokun, O.A., Yusuf, R.K., Adeleye, E.A., 2008. Seasonal changes in physicochemical parameters and nutrient load of river sediments in Ibadan city, Nigeria. Global NEST Journal 10 (3), 326-336.

Annual Reports of the Institute of Hydroecology and Ichthyology of Scientific Center of Zoology and Hydroecology NAS RA 2019. Report on major research outcomes for 2019 , issued by decision of the Presidium of NAS RA, N1 (1768) on 18 March of 2020. 66-69. (In Armenian).

Babanazarova, O., Sidelev, S., Schischeleva, S., 2013, The structure of winter phytoplankton in Lake Nero, Russia, a hypertrophic lake dominated by Planktothrix-like Cyanophyta. Aquatic Biosystems 9 (18). https://doi.org/10.1186/2046-9063-9-18
Badalyan, K., Stepanyan, L., Hambaryan, L., 2005. Study of some spaces of Cyanophyta in the phytoplankton of the River Hrazdan. Abstract's book of $3^{\text {rd }}$ Young Medics' International Conference. Armenian medical association, Yerevan, 37.

Barinova, S.S., Medvedeva, L.A., Anisimova, O.V., 2006. Bioraznoobrazie vodoroslej - indikatorov okrughajushej sredy [Biodiversity of algal indicators in environmental assessment]. Pilies Studio, TelAviv, Israel, 497 p. (In Russian).

Banerjee, A., 2020. Liver toxicity of chemical warfare agents. In: Gupta, R. (ed.), Handbook of Toxicology of Chemical Warfare Agents. Academic Press, Cambridge, USA, 659-671. https://doi. org/10.1016/B978-0-12-819090-6.00040-4

Carmichael, W.W., 1988. Toxins of freshwater algae. In: Tu, A.T. (ed.), Handbook of Natural Toxins, Marine Toxins and Venoms. Marcel Dekker, New York, USA, 121-157.

Chia, M.A., Jankowiak, J.G., Kramerb, B.J., Goleskib, J.A., Huang, I-Sh., Zimbac, P.V., Bittencourt-Oliveiraa, M. do Ca., Gobler, C.J., 2018. Succession and toxicity of Microcystis and Anabaena (Dolichospermum) blooms are controlled by nutrient-dependent allelopathic interactions. Harmful Algae 74, 67-77.

Chilingaryan, L.A., Mnacakanyan, B.P., Axababyan, K.A., Tokmajyan, H. V., 2002. Hydrography of rivers and lakes of Armenia. Agropress, Yerevan, Armenia, 49 p. (In Armenian).

Codd, G.A., 2000. Cyanophytal toxins, the perception of water quality, and the prioritisation of eutrophication control. Ecological Engineering 16, 51-60.

Gkelis, S., Zaoutsos, N., 2014. Cyanotoxin occurrence and potentially toxin producing Cyanophyta in freshwaters of Greece: a multidisciplinary approach. Toxicon 78, 1-9.

Hambaryan, L., Shahazizyan, I., 2014. Brief decisive, educational manual for genera of freshwater algae. YSU Press, Yerevan, Armenia, 61 p. (In Armenian).

Nikanorov, A.M., 2001. Gidrokhimia [Hydrochemistry]. Gidrometeoizdat, Saint-Petersburg, Russia, 447 p. (In Russian).

Proshkina-Lavrenko, A.I., Makarova, I.V., 1968. Vodorosli planktona Kaspijskogo morja [Planktonic algae of the Caspian Sea]. Nauka, Leningrad, USSR, 295 p. (In Russian). 
Prowse, G.A., 1969. The role of cultured pond fish in the control of eutrophication in lakes and dams. Internationale Vereinigung für Theoretische und Angewandte Limnologie: Verhandlungen 17 (2), 714-718.

Reynolds, C.S., Huszar, V., Kruk, C., NaselliFlores, L., Melo, S., 2002. Towards a functional classification of the freshwater phytoplankton. Journal of Plankton Research 24, 417-428.

Stepanyan, L.G., 2009. Hydrobiological and hydrochemical study of Hrazdan hydro ecosystem in the territory of Yerevan district. Biological sciences PhD thesis. Yerevan, Armenia, 142 p.(In Armenian).

Stepanyan, L.G, Hambaryan, L.R., Hovhannisyan, R.H., 2005. Study of phytoplankton community dynamics of the Hrazdan River in Yerevan area. Biological Journal of Armenia 57 (3-4), 257-264.
Streble, H., Krauter, D., 2001. Das Leben im Wassertropfen. Kosmos, Stuttgard, Germany, 415 p. (In German).

Swaminathan, M.S., 2003. Biodiversity: an effective safety net against environmental pollution. Environmental Pollution 126, 287-291.

Tsarenko, P.M., 1990. Kratkij opredelitel chlorokokovykh vodoroslej Ukrainskoj SSR [Short key of Chlorococcal Algae of Ukraine]. Naukova Dumka, Kiev, USSR, 106 p. (In Russian).

Yu, S.Z., Tang, Z.Y., Wu, M.C., Xia, S.S., 1989. Drinking water and primary liver cancer. In: Tang, Z.Y., Wu, M.C., Xia, S.S. (eds.), Primary Liver Cancer. China Academic Publisher, Beijing, China, 30-37. 